\title{
MEDIA, SINKHOLES, AND THE UK NATIONAL KARST DATABASE
}

\author{
Vanessa J. Banks \\ British Geological Survey, Environmental Science Centre, Nicker Hill, Keyworth, Nottingham NG12 5GG, United \\ Kingdom,vbanks@bgs.ac.uk
}

Helen J. Reeves

British Geological Survey, Environmental Science Centre, Nicker Hill, Keyworth, Nottingham NG12 5GG, United

Kingdom,hjre@bgs.ac.uk

Emma K. Ward

British Geological Survey, Environmental Science Centre, Nicker Hill, Keyworth, Nottingham NG12 5GG, United

Kingdom,eward@bgs.ac.uk

Emma R. Raycraft

British Geological Survey, Environmental Science Centre, Nicker Hill, Keyworth, Nottingham NG12 5GG, United

Kingdom,ecre@bgs.ac.uk

\section{Hannah V. Gow}

British Geological Survey, Environmental Science Centre, Nicker Hill, Keyworth, Nottingham NG12 5GG, United

Kingdom,hcullen@bgs.ac.uk

David J.R. Morgan

British Geological Survey, Environmental Science Centre, Nicker Hill, Keyworth, Nottingham NG12 5GG, United

Kingdom,djrm@bgs.ac.uk

\section{Donald G. Cameron}

British Geological Survey, Environmental Science Centre, Nicker Hill, Keyworth, Nottingham NG12 5GG, United

Kingdom,dgca@bgs.ac.uk

\section{Abstract}

The British Geological Survey (BGS) maintains a number of databases that feed into hazard susceptibility assessments, including karst, landslide, and mining susceptibility. The winter period from December 2013 to January 2014 was one of, if not the most, exceptional periods of winter rainfall in the last 248 years for England and Wales. During this period the Jet Stream diverted easterly tracking cyclones along a more southerly route than is usual across the United Kingdom (UK). This resulted in south-east and central-southern England experiencing total rainfall values of $372.2 \mathrm{~mm}$ for this period, which was the wettest two-month period since 1910. This period was associated with extensive flooding and increased numbers of slope failures, landslides, and sinkholes, which affected transport routes into and out of London, thereby generating considerable media attention. In addition to government and stakeholder requirements, the BGS experienced an unusually high level of enquiries from the public and the media pertaining to sinkholes, which put an additional strain on resources, but is an acknowledged component of the BGS remit. During February alone, the BGS received reports of 19 sinkholes. The majority of these occurred in the Cretaceous Chalk of southern England. Approximately half were not naturally occurring sinkholes, but were due to the collapse of anthropogenic features. Typically, the anthropogenic subsidence collapse features included: the collapse of chalk shafts associated with historic extraction of chalk for brickworks; the collapse of deneholes (medieval chalk workings for chalk for ground improvement), and chalk mine shaft collapses. This paper describes the National Karst Database, stakeholder requirements, and how the BGS has responded with new and improved mechanisms for data collection, storage and dissemination.

\section{Introduction}

Shallow geohazard and risk research at the British Geological Survey (BGS) is focused at a range of scales, from site-specific process understanding to national scale hazard susceptibility assessments. Results of these 
assessments are delivered through the product GeoSure. This product was driven by stakeholders (primarily the home insurance-sector) and comprises a series of national datasets providing geological information about potential ground movement or subsidence. More specifically, GeoSure comprises national scale (1:50,000) GIS-derived susceptibility maps for collapsible deposits, compressible ground, landslides, running sand, shrinkswell sediments, and soluble rocks (Figure 1). These maps are aimed at the non-scientific community and incorporate a simple hazard rating $(\mathrm{A}=$ low to $\mathrm{E}=$ high susceptibility). The main soluble rock types that are encountered in the UK comprise (in order of decreasing solubility and dissolution rate): Triassic salt, Permian gypsum and dolomite, Triassic gypsiferous rocks, Cretaceous chalk, Jurassic limestone, and Palaeozoic limestone. The susceptibility map was built by scoring each of these rock types based on differential weighting of lithology, topography, geomorphology, superficial cover type and superficial cover thickness (Farrant and Cooper, 2008). The knowledge behind the scoring methodology is partly derived from the understanding that comes from maintaining the National Karst Database. It was also enhanced by local knowledge and manual subdivisions. In particular, the evaporites have a slightly different set of determinative parameters that are calculated separately (Farrant and Cooper, 2008).

The National Karst Database, which is being populated and maintained by the BGS, aims to provide data pertaining to the distribution of dolines, stream sinks, caves, springs and incidences of building damage. This data is being retrieved from field slips and paper maps (with additional fine-scale data and groundtruthing derived from fieldwork), from remote sensing techniques such as Light Detection and Ranging (LiDAR) and from existing documentary data sources such as historical and modern Ordnance Survey maps, cave surveys, academic papers and historical documents. Other data such as a legacy "Applied Geology" database (more recently held by Peter Brett Associates) that was originally funded by the Department of the Environment during the 1990s, and the Mendip Cave Registry data are also being used to identify relevant features. This is a time-intensive data gathering exercise, which has been driven by the karst research interests of the scientists involved. Consequently, the data gathering has been very detailed; for example, there are seventeen attribute fields associated with springs.
Both GeoSure and the National Karst Database were designed to capture information on the distribution of naturally occurring karst features. However, during the winter of 2013-2014 an exceptional number of sinkholes were reported in the UK. A significant number of these were found to be anthropogenically derived. They had a significant impact on infrastructure and property, which captured the attention of the media, and consequently, the imagination of the public. This resulted in demands for data delivery comparable with that of the BGS National Landslide Database (Pennington et al., 2015), which was also adapted to incorporate anthropogenic slope failures as well as the core of natural landslides. Here we describe the triggering factors for the unusually high number of sinkhole events, the nature of the events, the demand on resources and how BGS has responded by developing new collaborations and a new portal for data delivery.

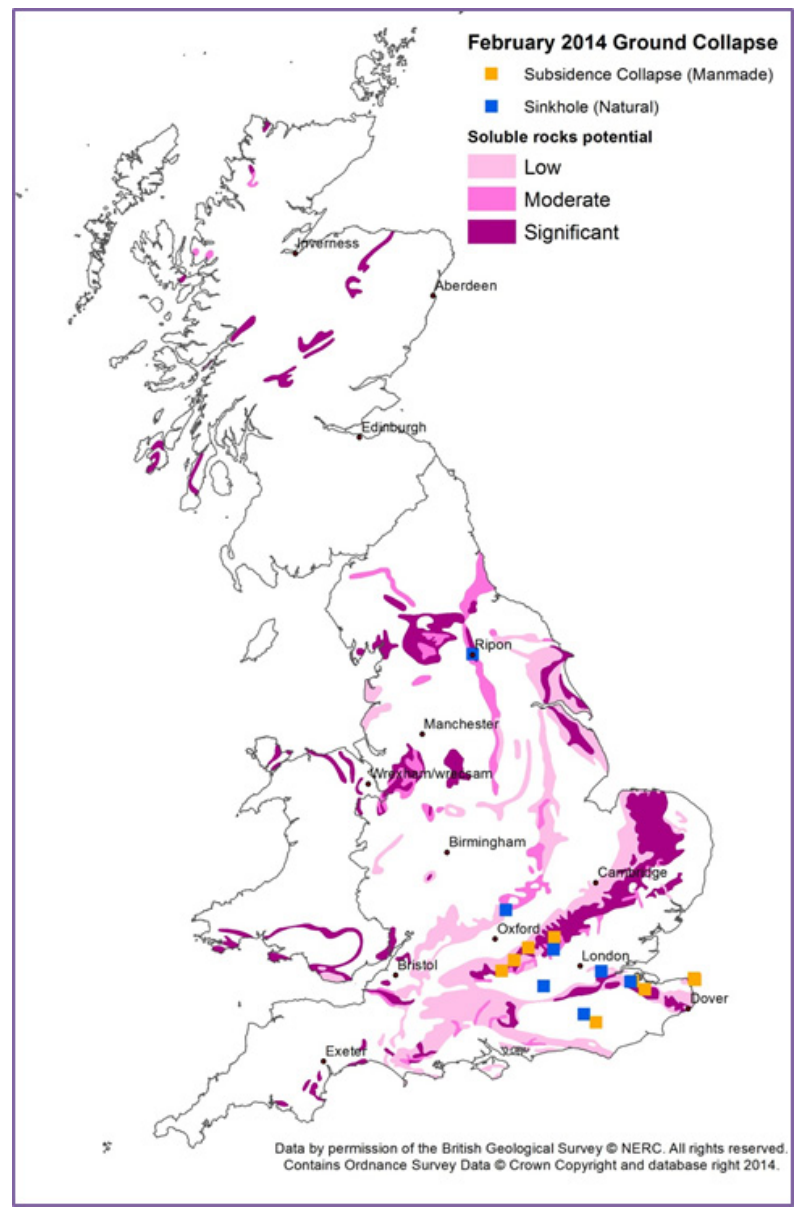

Figure 1. Soluble rock susceptibility map with February 2014 "sinkholes" superimposed. BGSONERC. Contains OS Open data@Crown Copyright and database rights, 2014. 


\section{The Unusual Weather Conditions During Winter 2013-2014}

On 21 February 2014, the UK Met Office reported on the winter storms of December 2013 to January 2014. They advised that this was one of, if not the most, exceptional periods of winter rainfall in the last 248 years for England and Wales. The rainfall total for December and January was $287.6 \mathrm{~mm}$ (119.9 and $167.7 \mathrm{~mm}$ respectively) for the southeast and central-southern England region, which was the wettest two-month period in their records from 1910. During February, there was a further $126.1 \mathrm{~mm}$ for the south and south-east. Between late January and mid-February, twelve storms hit the south and south-east making it the stormiest period of weather that the UK has experienced for at least twenty years (http://www.metoffice.gov. uk/research/news/2015/uk-winter-storms-one-yearon). The four storms from early to mid-February were particularly severe giving rise to strong winds and huge waves as well as significant rainfall. The sequence of storms was attributed to the position and strength of the Jet Stream, driving a succession of low pressure systems across the Atlantic in a marginally more southerly route than usual. The impact of the rapid succession of events was significant coastal erosion and extensive flooding, particularly of the Somerset Levels. Inevitably this resulted in self-questioning with respect to UK resilience. It is this sustained period of wet weather that is suspected to be the trigger for the spate of sinkholes and collapse subsidence features that were reported, primarily occurring in the south and south-east (Table 1; Figure 1).

Table 1. Sinkhole occurrences in February 2014.

\begin{tabular}{|c|c|c|c|}
\hline $\begin{array}{l}\text { Date in } \\
2014\end{array}$ & Location & $\begin{array}{l}\text { National Grid } \\
\text { Reference }\end{array}$ & Description \\
\hline 28 Jan & $\begin{array}{l}\text { Walkern Croft, Benington Road, } \\
\text { Walkern, Hertfordshire }\end{array}$ & 52852250 & Collapse of karst flow path \\
\hline 2 Feb & Walter's Ash, High Wycombe & 48391978 & $\begin{array}{l}\text { Suspected chalk mine shaft associated with former brickworks. Car } \\
\text { collapse into subsidence feature }\end{array}$ \\
\hline 6 Feb & Duddleswell, East Sussex & 54671285 & Collapse associated with disused soakaway \\
\hline $11 \mathrm{Feb}$ & M2 between junctions 5 and 6 & 59421590 & Suspected denehole. Considerable disruption to motorway traffic. \\
\hline \multirow[t]{2}{*}{$12 \mathrm{Feb}$} & $\begin{array}{l}\text { Rainham Mark Grammar School, } \\
\text { Gillingham, Kent }\end{array}$ & 58061668 & Collapse of brick capped denehole. \\
\hline & Upper Basildon & 45861763 & Associated with former brickworks and chalk mine. \\
\hline \multirow[t]{5}{*}{$13 \mathrm{Feb}$} & Gillingham Anchorian Rugby Club & 57861664 & Doline associated with feather edge of Thanet Beds over Chalk \\
\hline & $\begin{array}{l}\text { Oakridge Gardens, Wood Lane End, } \\
\text { Hemel Hempstead }\end{array}$ & 50752078 & Associated with former brickworks \\
\hline & Turner's Hill & 53531360 & Sand piping \\
\hline & $\begin{array}{l}\text { Warren Farm, Finmere, } \\
\text { Buckinghamshire }\end{array}$ & 46242332 & Collapse of karst flow path \\
\hline & $\begin{array}{l}\text { Holmesdale Grove, Barnehurst, } \\
\text { Bexley }\end{array}$ & 55131760 & Doline associated with feather edge of Thanet Beds over Chalk \\
\hline \multirow[t]{3}{*}{$16 \mathrm{Feb}$} & Croxley Green, Hertfordshire & 50711963 & Doline associated with Glacial sand and gravel over Chalk \\
\hline & Nettlebed, Oxfordshire & 47031863 & Chalk mines associated with former brickworks \\
\hline & Windermere Road, St Albans & 51692065 & Doline in chalk \\
\hline $17 \mathrm{Feb}$ & Magdalen's Road, Ripon & 43164719 & Doline formation due to gypsum dissolution below ground \\
\hline $20 \mathrm{Feb}$ & Devizes Road, Salisbury & 41341307 & Doline in Chalk \\
\hline $21 \mathrm{Feb}$ & Wilmington, Dartford, Kent & 55091707 & Doline \\
\hline $21 \mathrm{Feb}$ & Wilmington, Dartford, Kent & 55101703 & Doline \\
\hline $22 \mathrm{Feb}$ & Victoria Avenue, Broadstairs, Kent & 63801696 & Associated with brickworks \\
\hline $22 \mathrm{Feb}$ & Percy Avenue, Broadstairs, Kent & 63891707 & Associated with brickworks \\
\hline $26 \mathrm{Feb}$ & $\begin{array}{l}\text { Bridge House, High Street, Dartford, } \\
\text { Kent }\end{array}$ & 55431739 & $\begin{array}{l}3 \text { voids in garden area; suggested possibility of this being related to } \\
\text { former leats. Otherwise suspected natural dolines. }\end{array}$ \\
\hline $1 \mathrm{March}$ & Chilcompton, Somerset & 51602065 & Collapse of karst flow path \\
\hline
\end{tabular}




\section{"Sinkhole" Occurrences}

Whilst the true definition of a sinkhole describes a naturally occurring closed depression, the media uses this term primarily to describe any sudden opening of a cavity in the ground. It soon became clear that there was a demand for statistics regarding the extent of media interpreted "sinkhole" occurrences. A new Access database was initiated to serve this need. Twenty-four "sinkholes" were captured in this database for February 2014. The events were divided into eight categories (Figure 2), which can be grouped as 1) naturally occurring pipes in the chalk; 2) natural gypsum-related collapse; 3) shaft or mine collapses associated with former chalk workings (medieval deneholes or more recent workings associated with brick making), and 4) piping-related events on non-soluble bedrock. The naturally occurring dolines in chalk commonly occur close to the feather edge of the overlying Palaeogene strata or where the chalk is overlain by glacial or glacio-fluvial sands and gravel (suffosion dolines). It is suspected that water migrating through the capping materials reacts with pyrite (iron sulfide) in the granular strata, which causes a reduction in $\mathrm{pH}$ and therefore greater potential for dissolution of the chalk bedrock (Edmonds, 1983). The high percentage of collapse features associated with former brickworks is attributed to the historic practice of using locally-won wash mill ground chalk as an additive (up to $15 \%$ ) in brick making. The addition of chalk improved the brick firing process and gave a yellow hue to the bricks.

\section{Media Interest}

For BGS the media created a storm of a different kind. The "sinkholes" started to appear in early February and

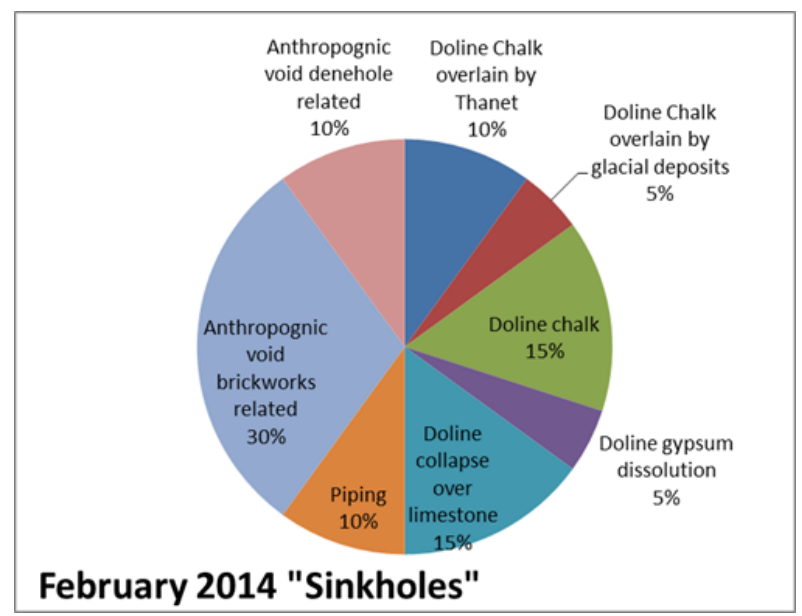

Figure 2. Pie chart to show break down of the types of "sinkhole". BGSONERC. the resultant newspaper headlines captured in Table 2 are typical. Interest seemed relentless, evolving from sensationalism to concerns about the cost implications for individuals. Requests for radio and television interviews of BGS staff were equally numerous. Whilst there was some benefit for BGS from the publicity, the requests placed a huge demand on already stretched resources.

\section{Enquiries and the Public}

Sensational headlines triggered the imagination of the British public, the consequence of which was a "flood" of enquiries (Figure 3), each one requiring an individual response. Many enquiries related directly to the reported incidents, requesting information on how to manage and remediate sinkholes, a number related to hazard susceptibility in specific areas underlain by soluble bedrock, some related to other types of foundation problem or subsidence and others were requests for further descriptions of how and where sinkholes occur. Unsurprisingly, there was increased interest from researchers, particularly undergraduate students undertaking independent research projects.

The increased number of enquiries to BGS appears to have stemmed from the amount of media coverage that the BGS was exposed to during this time and also from other public sector organisations providing BGS contact details. As with the media, public enquiries presented an extra strain on resources.

\section{State of Emergency}

The UK Civil Contingencies Act dictates what happens during emergencies with a requirement to ensure that relevant organisations collaborate. A state of emergency was declared and meetings of COBR (Cabinet Office Briefing Rooms), the emergencies committee, which includes the key people that are able to make things happen (ministers, senior officials and people from outside government, in this case including representatives from the Environment Agency, Ministry of Defence and Met Office), took place. Between Christmas and 5 February 2014, twenty-one COBR meetings had taken place, primarily to respond to the threat of floods. During February 2014 COBR was being informed by the Scientific Advisory Group for Emergencies (SAGE), which is responsible for coordinating and peer reviewing, as far as possible, scientific and technical advice to inform decision-making. A number of senior BGS staff were called upon to advise SAGE. 
Table 2. "Sinkhole" related newspaper headlines February 2014.

\begin{tabular}{|c|c|c|}
\hline Date & Newspaper & Headline \\
\hline 2 February 2014 & Bucks Free Press & Family evacuated from home after sinkhole swallows car \\
\hline \multirow[t]{2}{*}{3 February 2014} & Guardian & Sinkhole swallows car in High Wycombe \\
\hline & Mail & $\begin{array}{l}\text { The Home Counties sinkhole that swallowed a CAR! Family flee village home after their } \\
\text { VW disappears into } 30 \mathrm{ft} \text {-deep crater which appeared overnight. }\end{array}$ \\
\hline $\begin{array}{l}12 \text { February } \\
2014\end{array}$ & News Shopper & Giant sinkhole opens in Barnehurst back garden. \\
\hline $\begin{array}{l}14 \text { February } \\
2014\end{array}$ & Your Maidstone & Two more "sink holes" open in Medway \\
\hline $\begin{array}{l}16 \text { February } \\
2014\end{array}$ & Daily Mail & Terrifying sinkholes that are opening up all over Britain \\
\hline $\begin{array}{l}17 \text { February } \\
2014\end{array}$ & Huffington Post & $\begin{array}{l}\text { UK Weather: Homes evacuated as yet another giant sinkhole appears, this time in Hemel } \\
\text { Hempstead }\end{array}$ \\
\hline $\begin{array}{l}17 \text { February } \\
2014\end{array}$ & $\begin{array}{l}\text { International Business } \\
\text { Times }\end{array}$ & Sinkholes in the UK: Why is the ground collapsing? \\
\hline \multirow{4}{*}{$\begin{array}{l}18 \text { February } \\
2014\end{array}$} & The Telegraph & Why sinkholes are swallowing Britain \\
\hline & The Guardian & North Yorkshire home wrecked by ninth sinkhole in a month \\
\hline & Express & Sinking Britain! Now sinkholes even threaten the dead as they appear in a cemetery \\
\hline & Independent & What are sinkholes, how do they form and why are we seeing so many? \\
\hline $\begin{array}{l}19 \text { February } \\
2014\end{array}$ & Metro & Sinkholes: Why are they here and how do they happen? \\
\hline $\begin{array}{l}20 \text { February } \\
2014\end{array}$ & Mirror & $\begin{array}{l}\text { Why are so many sinkholes appearing in the UK? All you need to know about the } \\
\text { phenomenon }\end{array}$ \\
\hline $\begin{array}{l}21 \text { February } \\
2014\end{array}$ & The Guardian & Sinkholes on the increase after UK's wet weather \\
\hline $\begin{array}{l}24 \text { February } \\
2014\end{array}$ & Live Science & Sinkholes swallow more after UK's big storms \\
\hline $\begin{array}{l}26 \text { February } \\
2014\end{array}$ & Construction News & Sinkholes: can they be stopped? \\
\hline 4 March 2014 & Guardian & Sinkholes: there's good and bad news \\
\hline
\end{tabular}

The Government Chief Scientific Adviser particularly required information on hazard susceptibility, the numbers and distribution of "sinkholes" and landslides, and the processes associated with their occurrence to be made available to infrastructure managers.

\section{How BGS Has Responded}

In order to try and address the multiple needs of stakeholders BGS responded with updated web pages to provide information on what to do in the event of a sinkhole, case study reports on "sinkholes", and an updated map showing the distribution of sinkholes during February 2014. This enabled the provision of relevant information for the public and media enquiries. Case studies comprised reports on site visits to exemplify the different types of feature. For example, deneholes are medieval chalk extraction pits; characteristically they comprise a narrow shaft with a number of chambers radiating from the base. Chalk was extracted for soil improvement and was usually applied directly to the field, although sometimes it was first burnt in lime kilns to produce quicklime (calcium oxide). The addition of water to quicklime forms slaked lime (calcium hydroxide) a white powder, which can also be used in the preparation of mortar. Once they had reached their limits, the deneholes were commonly capped. A variety of capping techniques were used. Rainham Mark Grammar School, Gillingham, Kent provided an example of a denehole shaft collapse (Figure 4). Interestingly, this shaft was situated on relatively high ground, possibly reflecting the location of a former field boundary in an area with a relatively thin cover over the chalk. Figure 4 also shows the development of small dissolution pipes close to ground surface. Bricks in the base of the hole suggest that this feature may once have been capped with a brick arch. At one of the two northerly occurrences of sinkholes in February 2014, in Ripon, Yorkshire, a naturally occurring sinkhole, which 


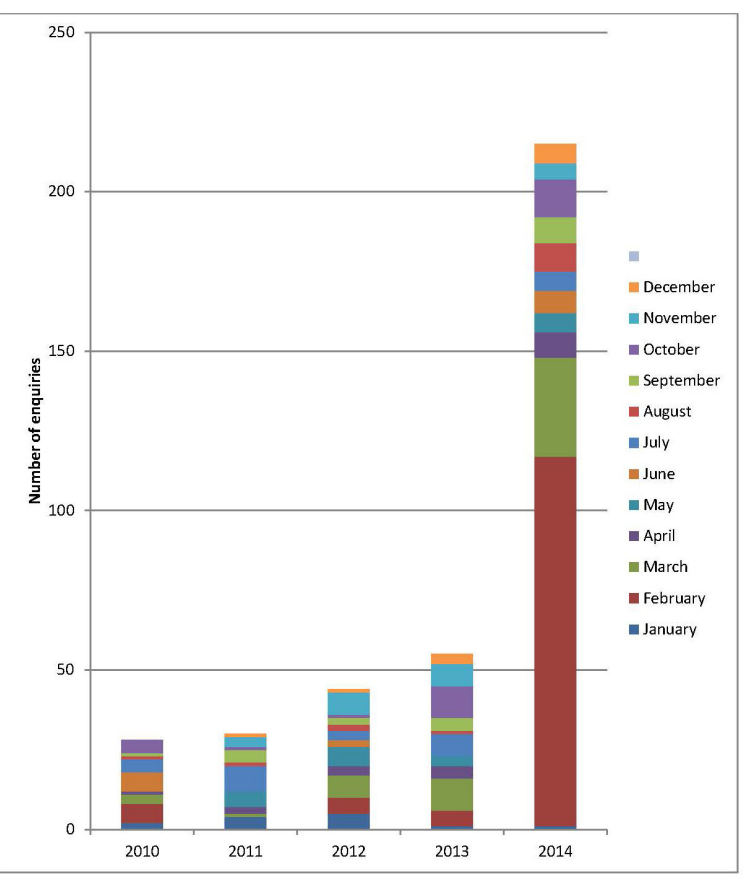

Figure 3. Increased number of "sinkhole" related enquiries during February 2014.

was roughly oval and approximately $11 \times 15 \mathrm{~m}$ and $0.7 \mathrm{~m}$ deep, resulted in large cracks within and evacuation of a detached property. This feature formed the focus of a second case study, characteristic of sinkholes in the Ripon area, which have been attributed to sub-surface, joint-guided dissolution of gypsum (Cooper et al., 2013).

In addition to the responsive work, the BGS has been addressing the requirements of a specific request from the London Fire Brigade; collaborating with the Chief Fire Officers Association Urban Search and Rescue (USAR) group to help develop standard operating procedures and training with respect to

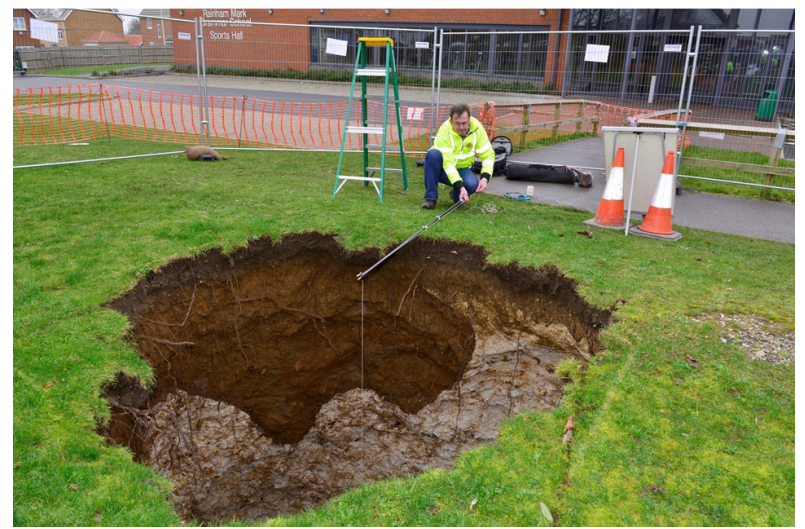

Figure 4a. Denehole collapse, Rainham Mark Grammar School, Gillingham, Kent. Photographs P Witney @BGS/NERC. karst geohazards. The demands of the media, public and SAGE for "sinkhole statistics" has led to a more proactive and systematic approach to the collection of "sinkhole data" through media searches.

There is a greater urgency to complete the population of the karst database. Further, there has been a focus on developing and adapting a chalk cavity database as an Oracle delivery portal for information on sinkholes and also the karst features captured in the karst database. This will ensure consistent delivery of quality-assured data to all stakeholders, including infrastructure managers, researchers and commercial organisations, or other landowners with geohazard interests. The Oracle database has been adapted to incorporate a greater number of feature types, such as shafts, boreholes, dolines and springs, with a rapid search facility for data extraction purposes.

\section{Lessons Learned}

Some key lessons have been learned from February 2014:

1. The increasing storminess and reduced predictability of weather patterns has the potential to impact the occurrence of geohazards, including collapse subsidence features.

2. The 24-hour media underpinned by modern technologies further increases the demands on resources at times of increased incidences of geohazards.

3. The data requirements of our stakeholders extended beyond susceptibility mapping to database creation of actual events in order to

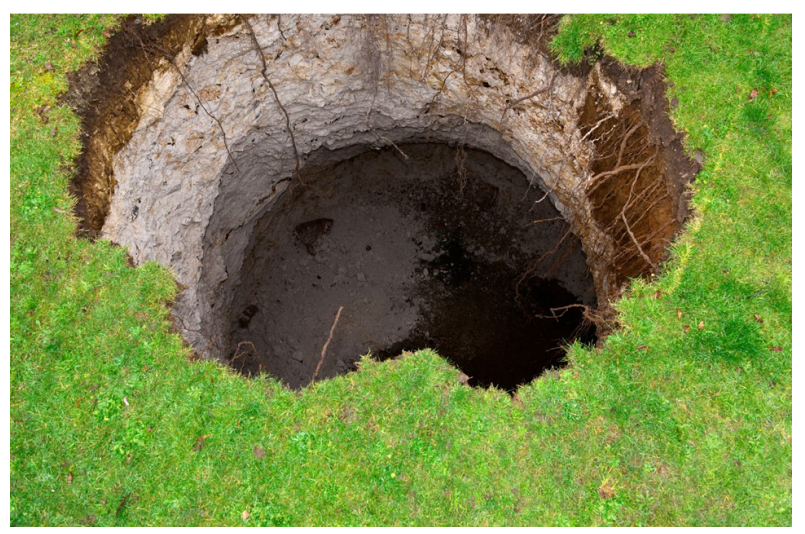

Figure 4b. Denehole collapse, Rainham Mark Grammar School, Gillingham, Kent. Photographs P Witney @BGS/NERC. 
provide temporal information. This required the development of new data capture and delivery mechanisms.

4. Public awareness of BGS services has been heightened, as is evident in the ongoing number of "sinkhole" related enquiries. It is suspected that this is partly due to the reduction in local government funding, resulting in the public seeking new ways of addressing planning and building enquiries.

5. Increased interest from research students has continued, but is tending towards a focus on impact rather than process understanding, which will require further development of our datasets.

\section{Acknowledgements}

Banks, Reeves, Ward, Raycraft, Gow, Morgan and Cameron publish with the permission of the Executive Director of the British Geological Survey, NERC and extend our thanks to our colleagues A.H. Cooper and A.R. Farant who developed the karst database.

\section{References}

Cooper AH, Odling NE, Murphy PJ, Miller C, Greenwood CJ, Brown DS. 2013. The role of sulfate-rich springs and groundwater in the formation of sinkholes over gypsum in Eastern England. In: Land L, Doctor DH, Stephenson JB (editors.) Sinkholes and the Engineering and Environmental Impacts of Karst: Proceedings of the Thirteenth Multidisciplinary Conference, May 6-10. National Cave and Karst Research Institute, Carlsbad, New Mexico, 141-150.

Edmonds CN. 1983. Towards the prediction of subsidence risk upon the Chalk outcrop. Quarterly Journal of Engineering Geology and Hydrogeology 16: 261-266. http://dx.doi. org/10.1144/GSL.QJEG.1983.016.04.03.

Farrant AR, Cooper AH. 2014. A hole lot of trouble. Geoscientist 24 (6): 12-17.

Farrant AR, Cooper AH. 2008. Karst geohazards in the UK: the use of digital data for hazard management. Quarterly Journal of Engineering Geology and Hydrogeology 41: 339-356.

Pennington C, Freeborough K, Dashwood C, Dijkstra T, Lawrie K. 2015. The National Landslide Database of Great Britain: acquisition, communication and the role of social media. Geomorphology [In press, corrected proof] http://dx.doi.org/10.1016/j. geomorph.2015.03.013.
Reviewing the 2013-2014 UK winter storms [Internet]. 2015. [Place of publication unknown]: http:// www.metoffice.gov.uk/; [updated 2015 February 6; cited 2015 March 1]. Available from: http:// www.metoffice.gov.uk/research/news/2015/ukwinter-storms-one-year-on. 
